\title{
Internal communication, employee participation, job satisfaction, and employee performance
}

\author{
Waiphot Kulachai, Piya Narkwatchara, Pralong Siripool, \& Kasisorn Vilailert \\ Burapha University, Chonburi, Thailand
}

\begin{abstract}
The main objective of this research was to examine relationship between internal communication, employee participation, job satisfaction, and employee performance. The samples of this study were 489 state officials from 10 city municipalities in Chonburi (Thailand). Questionnaire was employed to collect the primary data which later were analyzed using structural equation modeling technique. The results indicated that internal communication had positive influence on employee participation and job satisfaction. Employee participation also had positive influence on job satisfaction. However, it did not have an influence on job performance of the employees. Furthermore, employee participation and job satisfaction played the mediating role in the relation between internal communication and job performance of the employees.

Keywords: communication, employee participation, job satisfaction, employee performance
\end{abstract}

\section{INTRODUCTION}

Robbins \& Judge (2017) defined communication as "the transfer and the understanding of meaning." It plays important roles in management, feedback, emotional sharing, persuasion, and information exchange. There are two kinds of communication known as formal and informal communication. The former one is established by an organization to transmit message and information to its members. The latter one is a communication channel created spontaneously depending on individual preferences. When consider on the direction of the communication. It can be divided into two directions; downward and upward communication. It is an important factor enhancing management effectiveness and strategic decision making (David 2005).

Communication in organization also plays important role in enhancing participation of employees. When employees have an opportunity to participate in decision making, they will feel that they are important persons for the organization. On the other hand, insufficient or limited employee participation in decision making will result in low level of job satisfaction, organizational commitment, employee engagement. It also leads to high level of intention to quit (Bonache 2005). Previous studies revealed that internal communication had positive impact on employee engagement (Ruck 2012). Therefore, the first hypothesis was proposed as follow:

H1: Internal communication has positive impact on employee participation

Internal communication is one of key factors enhancing employees to satisfy their job (Touranil \& Rast 2012). Previous studies (Chen 2008, Carrière \& Bourque 2009, Milan et al. 2013) found positive relationship between internal communication and job satisfaction. It also affected communication satisfaction, and organizational commitment. However, internal communication system should be designed to meet the information needs of organization's members (Carrière \& Bourque 2009). Therefore, the second hypothesis was proposed as follow:

$\mathrm{H} 2$ : Internal communication has positive impact on job satisfaction. 
Effective internal communication can enhance organizational performance (Chen 2008). However, managers should understand the communication process so they can design the communication system to meet the organizational needs (Kinicki \& Kreitner 2009). Communication also results in employee job performance. Previous studies found positive relationship between internal communication and job performance of employees (Asamu 2014, Bhatia \& Balani 2015). Therefore, the third hypothesis was proposed as follow:

H3: Internal communication has positive impact on employee performance

Employee participation provides positive consequences for organizations. Participation in initiatives environment can lead to high level of employee engagement, and lower level of intention to quit (Benn et al. 2015). A study by Appelbaum et al. (2013) suggested that insufficient participation in decision making resulted in low level of employee job satisfaction and employee commitment. In this study, we focused on relationship between employee participation and job satisfaction. Hence, the fourth hypothesis was proposed as follow:

H4: Employee participation has positive impact on job satisfaction

Relationship between employee participation and job performance had been studied by some scholars (Harter, Schmidt \& Hayes 2002; The Gallop Organization 2004, Balain \& Sparrow 2009). They found positive relationship between employee involvement and job performance. Patterson et al. (2004) noted that employee involvement could enhance employee performance and resulted in company productivity. Therefore, the fifth hypothesis was proposed as follow:

H5: Employee participation has positive impact on job performance

Improving employee performance is necessary for an organization to gain a competitive advantage. However, to reach such goal, the organization should ensure that its employees are satisfied with their jobs. Siengthai \& Pila-Ngarm (2016) stated that there is positive relationship between job satisfaction and job performance of employees. In addition, Yousef (1998) found the relationship between satisfaction with job security and job performance of employees in a multicultural non-Western environment. However, a study by Yang \& Hwang (2014) found bilateral relationship between job satisfaction and job performance. Hence, the $6^{\text {th }}$ hypothesis was proposed as follows:

H6: Job satisfaction has positive impact on job Performance

\section{RESEARCH METHODS}

\subsection{Sample}

The samples of this study were 489 state officials from 10 city municipalities in Chonburi (Thailand). The majority of the respondents were female accounting for $64 \%$. Most of them were single (49\%) and hold bachelor degree (56\%). The average age and tenure of the respondents was 37 and 10 years respectively. Their average income was 19,400 Thai Baht.

\subsection{Measures}

Internal communication, a three items Likert's scale survey question was anchored by strongly agree and strongly disagree. The measurement provided an alpha reliability of 0.89 .

Employee participation, a four items Likert's scale survey question was anchored by strongly agree and strongly disagree. The measurement provided an alpha reliability of 0.88 .

Job satisfaction, a four items Likert's scale survey question was anchored by strongly agree and strongly disagree. The measurement provided an alpha reliability of 0.86 .

Job performance, a four items Likert's scale survey question was anchored by strongly agree and strongly disagree. The measurement provided an alpha reliability of 0.85 .

The data were analyzed using descriptive statistics, such as mean, frequency, percentage, and standard deviation. The validity of the measurement models was tested using confirmatory factor analysis (CFA). The authors also employed structural equation modeling (SEM) analysis to test the hypotheses.

\section{RESULTS AND DISCUSSIONS}

\subsection{Confirmatory factor analysis}

The confirmatory factor analysis (CFA) was conducted to test the validity of the measurement models. Figure 1 illustrated the result of CFA and overall fit details are showed in Table 1.

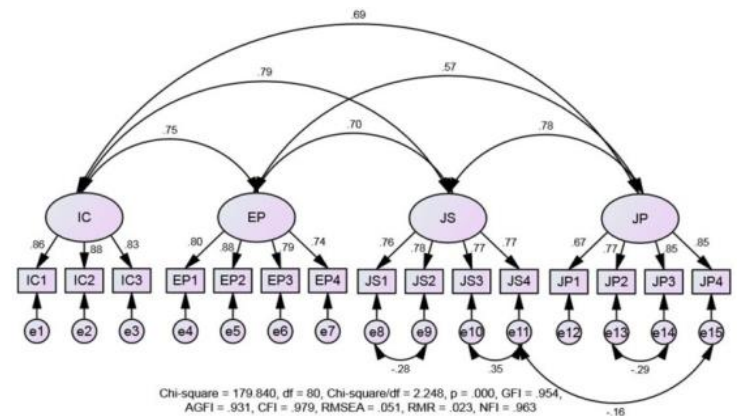

Figure 1 Standardized path estimates for the hypothesized SEM model 
Table 1 CFA results

\begin{tabular}{lll}
\hline \multicolumn{1}{c}{ Goodness of fit index } & \multicolumn{1}{c}{$\begin{array}{c}\text { Acceptable } \\
\text { Value }\end{array}$} & \multicolumn{1}{c}{ Results } \\
\hline Chi-square & Sig. is expected & $\mathrm{p}=0.000$ \\
\hline Absolute fit measures & & \\
GFI & $>0.90$ & 0.954 \\
RMSEA & $<0.07$ & 0.051 \\
RMR & Low & 0.023 \\
$\quad$ Normed Chi-square & $2-5$ & 2.248 \\
\hline Incremental fit indices & & \\
NFI & Approach to 1 & 0.963 \\
CFI & $>0.92$ & 0.979 \\
RFI & Approach to 1 & 0.951 \\
\hline Parsimony fit indices & & \\
AGFI & Approach to 1 & 0.931 \\
PNFI & Approach to 1 & 0.734 \\
\hline
\end{tabular}

Source: Hair et al. (2014)

Table 1 includes selected fit statistic from the CFA output. The overall model chi-square is 179.840 with 80 degree of freedom. The p-value associated with the result is .000 . This p-value is significant using the Type 1 error rate .05. Thus, the chisquare goodness of fit statistic does not indicate that the observed covariance matrix matches the estimated covariance matrix within sampling variance. However, this study has the sample size of 489. The significant $\mathrm{p}$-value is expected according to Hair et al. (2014). The value of RMSEA, an absolute fit index, is .051. This value indicates additional support for model fit. The normed Chi-square is 2.248 is considered acceptable fit for the CFA model. According to the incremental fit indices, the CFI has a value of .979 which exceeds the suggested cutoff values. In addition, the AGFI has the value of .931 which reflects moderate model fit.

\subsection{Structural equation modeling}

According to the analysis, all exogenous latent variables in the SEM model were allowed to covary in the hypothesized model (Kline, 2005). The fit indices of initial SEM test for the hypothesized model are presented in Table 2.

Table 2 Comparison of goodness-of-fit measures between hypothesized SEM model and CFA model

\begin{tabular}{lcc}
\hline Goodness of fit index & CFA model & SEM model \\
\hline Absolute fit measures & & \\
Chi-square & 179.840 & 270.012 \\
Degree of freedom & 80 & 85 \\
p-value & 0.000 & 0.000 \\
Normed Chi-square & 2.248 & 3.177 \\
GFI & 0.954 & 0.930 \\
RMSEA & 0.051 & 0.067 \\
RMR & 0.023 & 0.029 \\
\hline
\end{tabular}

Table 2, cont.

\begin{tabular}{lll}
\hline Incremental fit indices & & \\
NFI & 0.963 & 0.944 \\
CFI & 0.954 & 0.961 \\
RFI & 0.951 & 0.931 \\
\hline Parsimony fit indices & & \\
AGFI & 0.931 & 0.901 \\
PNFI & 0.734 & 0.764 \\
\hline
\end{tabular}

The information in this table illustrates the overall fit statistics from testing the hypothesized model. The chi-square is 270.012 with 85 degree of freedom $(\mathrm{p}<0.05)$, and the normed chi-square is 3.177. The model CFI is 0.961 with RMSEA of 0.067. All of these measures are within a range that would be associated with good fit. These suggest that the model provides overall good fit. The overall model fit changed very little from the CFA model. The standardized path coefficients are illustrated in Figure 2.

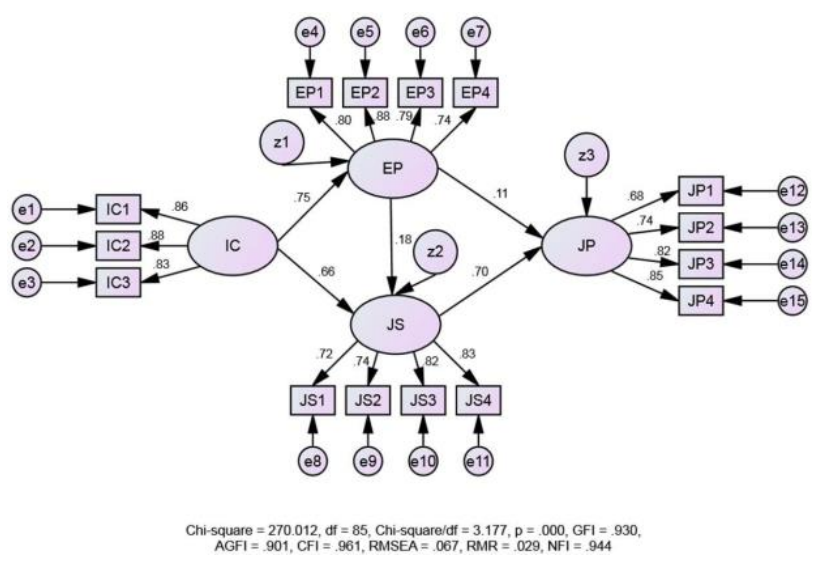

Figure 2 Hypothesized SEM model

Based on the residuals and modification indices information from the initial SEM model, we conducted the post hoc analysis allowing covary between errors of estimation. Then, the model was reestimated. The model fit statistics are shown in Table 3 and Figure 3.

Table 3 Comparison of goodness-of-fit measures between hypothesized SEM model and revised SEM model

\begin{tabular}{lcc} 
Goodness of fit index & $\begin{array}{c}\text { Hypothesized } \\
\text { model }\end{array}$ & Revised model \\
\hline Absolute fit measures & & \\
Chi-square & 270.012 & 149.189 \\
Degree of freedom & 85 & 80 \\
p-value & 0.000 & 0.000 \\
Normed Chi-square & 3.177 & 1.865 \\
GFI & 0.930 & 0.961 \\
RMSEA & 0.067 & 0.042 \\
MR & 0.029 & 0.019 \\
\hline
\end{tabular}


Table 3, cont.

\begin{tabular}{lll}
\hline Incremental fit indices & & \\
NFI & 0.944 & 0.969 \\
CFI & 0.961 & 0.985 \\
RFI & 0.931 & 0.959 \\
\hline Parsimony fit indices & & \\
AGFI & 0.901 & 0.942 \\
PNFI & 0.764 & 0.738 \\
\hline
\end{tabular}

Table 3 illustrates the overall fit statistics from testing the revised model. The chi-square is 270.012 with 80 degree of freedom $(\mathrm{p}<0.05)$, and the normed chi-square is 1.865 . The model CFI is .985 with RMSEA of 0.042. All of these measures are within a range that would be associated with good fit. These suggest that the model provides overall good fit. The overall model fit changed very little from the hypothesized model. The standardized path coefficients are illustrated in Figure 3.

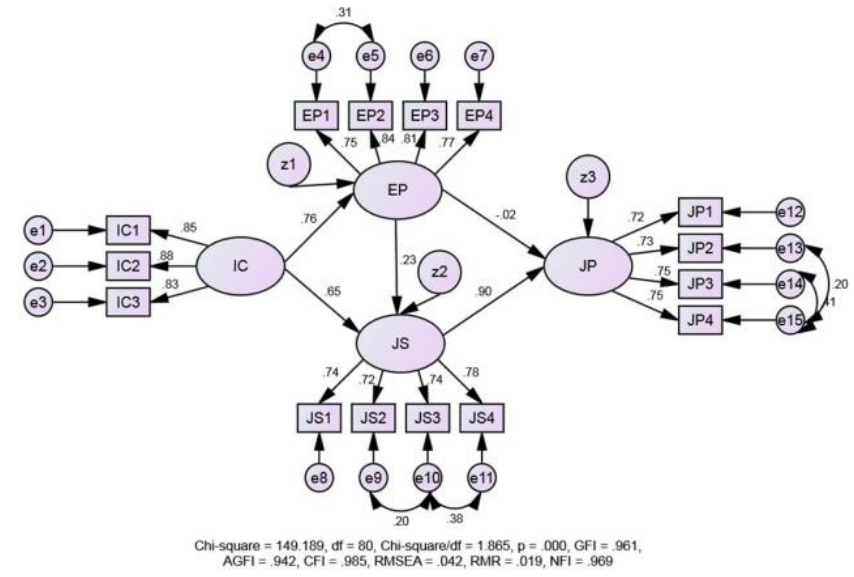

Figure 3 Revised SEM model

\section{CONCLUSION}

The results indicated that internal communication had positive influence on employee participation which was consistent with the study of Ruck (2012). The findings also supported the results of previous studies (Chen 2008, Carrière \& Bourque 2009, Tourani \& Rast 2012, Milan et al. 2013) which found positive relationship between internal communication and job satisfaction of the employees. The authors found that employee participation also had positive influence on job satisfaction which supported the findings of previous studies (Appelbaum et al. 2013). However, it did not have an influence on job performance of the employees. Furthermore, employee participation and job satisfaction played the mediating role in the relation between internal communication and job performance of the employees. This can be implied that internal communication would enhance employees to satisfy with their job.
The more likely they are happy with their jobs; the greater job performance they will have.

Job satisfaction is the most important factor affecting employees' performance. It is enhanced by effective internal communication and employee participation. To gain better organizational and employee performance, executives should improve the internal communication to meet the needs of the organization.

\section{REFERENCES}

Appelbaum, S.H. et al. 2013. Participation in decision making: a case study of job satisfaction and commitment (part three). Industrial and Commercial Training 45(7): 412-419. Asamu,

F.F. 2014. The impact of communication on workers' performance in selected organisations in Lagos State, Nige- ria. IOSR Journal of Humanities And Social Science, 19(8): 75-82.

Balain, S. \& Sparrow, P. 2009. Engaged to perform: A new perspective on employee engagement: Executive Summary. Lancaster University Management School.

Bhatia, K. \& Balani, M. 2015. Effective internal communication: A crucial factor affecting employee performance. Proceedings of International Conference on Management,Economics and Social Sciences, 21-22 November, 2015, Dubai, United Arab Emirates.

Carrière, J., \& Bourque, C. 2009. The effects of organizational communication on job satisfaction and organizational commitment in a land ambulance service and the mediating role of communication satisfaction. Career Development International 14(1): 29-49.

Chen, N. 2008. Internal/employee communication and organizational effectiveness: a study of Chinese corporations in transition. Journal of Contemporary China 17(54): 167189.

Benn, S., Teo, S.T.T., \& Martin, A. 2015. Employee participation and engagement in working for the environment. Personnel Review 44(4): 92-510.

Bonache, J. 2005.Job satisfaction among expatriates, repatriates and domestic employees: The perceived impact of international assignments on work-related variables. Personnel Review 34(1): 110-124.

David, F. R. 2005. Strategic management: Concepts and cases (10 ${ }^{\text {th }}$ ed.). Upper Saddle River: Pearson/Prentice Hall. Journal of Applied Psychology, 87(2): 268-279.

Harter, J.K., Schmidt, F.L., \& Hayes, T.L. 2002.Business-unitlevel relationship between employee satisfaction, employee engagement, and business outcomes: a meta-analysis

Kinicki, A., \& Kreitner, R. 2009. Organizational behavior ( $4^{\text {th }}$ ed.). New York: McGraw-Hill /Irwin.

Kline, R.B. 2005. Principles and practice of structural equation modeling. NY: The Guilford Press.

Milan, N. et al. 2013. The impact of internal communication satisfaction dimensions on job satisfaction dimensions and 
the moderating role of LMX. Public Relations Review 39(5): 563-565.

Robbins, S., \& Judge, T. 2017. Organizational behavior $\left(17^{\text {th }}\right.$ ed.). Essex: Pearson Education Limited.

Siengthai, S., \& Pila-Ngarm, P. 2016. The interaction effect of job redesign and job satisfaction on employee performance. Evidence-based HRM: a Global Forum for Empirical Scholarship 4(2): 162-180.

Tourani, A., \& Rast, S. 2012. Effect of employees' communication and participation on employees' job satisfaction: An empirical study on airline companies in Iran. The $2^{\text {nd }}$ International Conference on Economics, Trade and Development IPEDR, Singapore.

Yang, C.L., \& Hwang, M. 2014. Personality traits and simultaneous reciprocal influences betweenjob performance and job satisfaction. Chinese Management Studies 8(1): 6-26.

Yousef, D.A. 1998. Satisfaction with job security as a predictor of organizational commitment and job performance in a multicultural environment. International Journal of Manpower 19(3): 184-194. 